\title{
Digital Media and the Arab Spring
}

\author{
Philip N. Howard \& Muzammil M. Hussain
}

Philip N. Howard is associate professor at the University of Washington. He is the author of The Digital Origins of Dictatorship and Democracy: Information Technology and Political Islam (2010). Muzammil M. Hussain is a doctoral student in communication at the University of Washington.

As has often been noted in these pages, one world region has been practically untouched by the third wave of democratization: North Africa and the Middle East. The Arab world has lacked not only democracy, but even large popular movements pressing for it. In December 2010 and the first months of 2011, however, this situation changed with stunning speed. Massive and sustained public demonstrations demanding political reform cascaded from Tunis to Cairo, Sana'a, Amman, and Manama. This inspired people in Casablanca, Damascus, Tripoli, and dozens of other cities to take to the streets to call for change.

By May, major political casualties littered the ground: Tunisia's Zine al-Abidine Ben Ali and Egypt's Hosni Mubarak, two of the region's oldest dictators, were gone; the Libyan regime of Muammar Qadhafi was battling an armed rebellion that had taken over half the country and attracted NATO help; and several monarchs had sacked their cabinets and committed to constitutional reforms. Governments around the region had sued for peace by promising their citizens hundreds of billions of dollars in new spending of various kinds. Morocco and Saudi Arabia appeared to be fending off serious domestic uprisings, but as of this writing in May 2011, the outcomes for regimes in Bahrain, Jordan, Syria, and Yemen remain far from certain.

There are many ways to tell the story of political change. But one of the most consistent narratives from civil society leaders in Arab countries has been that the Internet, mobile phones, and social media such as Facebook and Twitter made the difference this time. Using these technologies, people interested in democracy could build extensive networks, create social capital, and organize political action with a speed and on a scale never seen before. Thanks to these technologies, virtual networks materialized in the streets. Digital media became the tool that allowed social movements to reach once-unachievable goals, even as authoritarian forces moved with a dismaying speed of their own to devise both high- and low-tech countermeasures. Looking back over the last few months of the Arab Spring, what have we learned about the role of digital media in political uprisings and democratization? What are the implications of the events that we have witnessed for our understanding of how democratization actually works today?

\section{Tunisian Origins}

On 17 December 2010, Mohamed Bouazizi set himself on fire. The young street vendor in the small Tunisian city of Sidi Bouzid had tried in vain to fight an inspector's small fine, appealing first to the police, then to town officials, and then to the regional governor. Each time he dared to press his case, security officials beat him. Bruised, humiliated, and frustrated by this cruel treatment, Bouazizi set himself alight in front of the governor's office. By the time he died 
in a hospital on January 4, his plight had sparked nationwide protests. The news had traveled fast, even though the state-run media had ignored the tragedy and the seething discontent in Sidi Bouzid. During the angry second half of December, it was through blogs and text messages that Tunisians experienced what the sociologist Doug McAdam calls "cognitive liberation.” In their shared sympathy for the dying man, networks of family and friends came to realize that they shared common grievances too. ${ }^{1}$ The realization hit home as people watched YouTube videos about the abusive state, read foreign news coverage of political corruption online, and shared jokes about their aging dictators over SMS. Communicating in ways that the state could not control, people also used digital media to arrive at strategies for action and a collective goal: the deposition of a despot.

For years, the most direct accusations of political corruption had come from the blogosphere. Investigative journalism was almost solely the work of average citizens using the Internet in creative ways. Most famous is the YouTube video showing Tunisia's presidential jet on runways near exclusive European shopping destinations, with onscreen graphics specifying dates and places and asking who was using the aircraft (the suggestion being that it was Ben Ali's high-living wife). Once this video appeared online, the regime cracked down on YouTube, Facebook, and other applications. But bloggers and activists pushed on, producing alternative online newscasts, creating virtual spaces for anonymous political discussions, and commiserating with fellow citizens about state persecution. With Bouazizi's death, Ben Ali's critics moved from virtual to actual public spaces. Shamseddine Abidi, a 29-year-old interior designer, posted regular videos and updates to Facebook. Al Jazeera used the content to carry news of the events to the world. Images of a hospitalized Bouazizi spread via networks of family and friends. An online campaign called on citizens and unions to support the uprising in Sidi Bouzid. Lawyers and students were among the first to take to the streets in an organized way.

The government tried to ban Facebook, Twitter, and video sites such as DailyMotion and YouTube. Within a few days, however, people found a workaround as SMS networks became the organizing tool of choice. Less than 20 percent of the population actively used social media, but almost everyone had access to a mobile phone. Outside the country, the hacker communities of Anonymous and Telecomix helped to cripple the government by carrying out denial-ofservice attacks and by building new software to help activists get around state firewalls. The government responded by jailing a group of bloggers in early January. For the most part, however, the political uprising was leaderless in the classic sense-there was no longstanding revolutionary figurehead, traditional opposition leader, or charismatic speechmaker to radicalize the public. But there were prominent nodes in the digital networks, people whose contributions held sway and mobilized turnout. Slim Amamou, a member of the copyright-focused Pirate Party, blogged the revolution (and later took a post in the national-unity government). Sami ben Gharbia, a Tunisian exile, monitored online censorship attempts and advertised workarounds. The middle-class Tunisian rapper who calls himself El Général streamed digital "soundtracks for the revolution."

By early January, urgent appeals for help and mobile phone videos of police repression were streaming across North Africa. Ben Ali's position seemed precarious. There were major protests in Algeria, along with several self-immolations. Again, the state-run news media covered little about events in neighboring Tunisia. The Algerian government tried to block Internet access and Facebook use as traffic about public outrage next door increased. But with all the privately owned submarine cables running to Europe, Algerian authorities lacked an effective 
chokepoint to squeeze. When the government also became a target for Anonymous, the state's own information infrastructure suffered.

By the time Ben Ali fled Tunisia for Saudi Arabian exile on January 14, civildisobedience campaigns against authoritarian rule were growing in Jordan, Oman, and Yemen. In other countries, such as Lebanon, Mauritania, Saudi Arabia, and Sudan, minor protests erupted on a range of issues and triggered quick concessions or had little impact. But even in these countries, opposition leaders drew inspiration from what they were tracking in Tunisia. Moreover, opposition leaders across the region were learning digital tricks for catching a ruling elite off guard. Compared to Tunisia, only Egypt had a more wired civil society, and the stories of success in Tunisia helped to inspire the largest protests that Cairo had seen in thirty years.

\section{Egypt, Inspired}

In Egypt, almost everyone has access to a mobile phone. The country also has the region's second-largest Internet-using population (only Iran's is bigger). News of Ben Ali's departure spread rapidly in Egypt, where the state-run media gave his exit grudging coverage even while continuing to move slowly on reporting the larger story of region-wide protests, including the demonstrations that were breaking out in Cairo.

Like Tunisia, Egypt has long had a large and active online public sphere frequented by banned political parties, radical fundamentalists, investigative journalists, and disaffected citizens. The state could not shut it down entirely: When the online news service of the Muslim Brotherhood (MB) was banned, for instance, servers were found in London and the organization continued to convey its views across the ether. But more than any established group, what turned anti-Mubarak vitriol into civil disobedience was a campaign to memorialize a murdered blogger.

Local Google executive Wael Ghonim started the Facebook group "We are All Khaled Said" to keep alive the memory of the 28-year-old blogger, whom police had beaten to death on 6 June 2010 for exposing their corruption. Just as digital images of Bouazizi in the hospital passed over networks of family and friends in Egypt, an image of Said's grotesquely battered face, taken by his brother as Khaled's body lay in the Alexandria city morgue, passed from one mobile phone camera to thousands. And just as the 26-year-old Iranian woman Neda AghaSoltan became a protest icon after her death at the hands of a regime sniper during postelection demonstrations in Tehran was caught on camera in June 2009, so did Said and his memorial Facebook page become a focus for collective dissent and commiseration. But more than being a digital tribute to someone from a group long tormented by Egyptian police, the Said webpage became a logistical tool, and at least temporarily, a strong source of community. Ghonim quickly emerged as Egypt's leading voice on Twitter, linking a massive Arabic-speaking social network with networks of mostly English-speaking observers and well-wishers overseas.

The first demonstrators to venture into Cairo’s Tahrir (Liberation) Square on 25 January 2011 shared many hopes and aspirations with their counterparts in Tunis. They were a similar community of like-minded individuals, educated but underemployed (in a "youth-bulge" society chronically unable to create enough jobs for its legions of young people), eager for change but committed neither to religious fervor nor political ideology. They found solidarity through digital media, and then used their mobile phones to call their social networks into the streets. Protests scaled up quickly, leaving regime officials and outside observers alike surprised that such a large network of relatively liberal, peaceful, middle-class citizens would mobilize against Mubarak with such speed. Islamists, opposition-party supporters, and union members were there too, but 
liberal and civil society voices dominated the digital conversation. News about and speeches by Mubarak, U.S. president Barack Obama, and regional leaders were streamed live to the phones and laptops in the square.

In the last week of January, an increasingly desperate Mubarak tried to unplug his country. His attempt to cut Egyptians off from the global information infrastructure met with mixed success. Anticipating the maneuver, tech-savvy students and civil society leaders had put in place backup satellite phones and dial-up connections to Israel and Europe, and were able to maintain strong links to the rest of the world. It appears, moreover, that some of the telecommunications engineers charged with choking off Internet access were slow to move. The first large Internet service provider received the shutdown order on Friday, January 28, but took no action until Saturday. Others responded promptly, but restored normal service on Monday. For four days, the amount of bandwidth going into Egypt dropped, but it was far short of the information blackout that Mubarak had been seeking. The regime had to deal with costs and perverse effects, too. Government agencies were crippled by being knocked off the grid. And middle-class Egyptians, denied home Internet access, took to the streets in larger numbers than ever, many driven by an urge simply to find out what was going on.

A few days later, the Egyptian security services began using Facebook and Twitter to anticipate the movements of individual activists. They abducted Ghonim once his Facebook group topped three-hundred thousand members (it is now has four times that many). Digital media technologies not only set off a cascade of civil disobedience across Egypt, but made for a unique means of civic organizing that was replicated around the region.

\section{The Digital Contagion of Democracy}

Digital media spread the details of successful social mobilization against the strongmen of Tunisia and Egypt across the region. As had happened in Tunisia and Egypt, authorities in Algeria, Bahrain, Libya, Saudi Arabia, and Syria tried to stifle digital conversation about domestic political change. These governments also targeted bloggers with arrests, beatings, and harassment. It is clear that digital media have played an important role. Images of jubilant protesters in Tunisia inspired others across the region. Facebook provided an invaluable logistical infrastructure for the initial stages of protest in each country. Text-messaging systems fed people within and outside these countries with information about where the action was, where the abuses were, and what the next step would be.

Within a few weeks, there were widely circulating PDFs of tip sheets on how to pull off a successful protest. The Atlantic Monthly translated and hosted an "Activist Action Plan," boingboing.net provided tips for protecting anonymity online, and Telecomix circulated the ways of using landlines to circumvent state blockages of broadband networks. Through Google Earth, the Shias of Bahrain - many of whom live in one-room houses with large families — could map and aggregate photographs of the ruling Sunni minority’s opulent palaces. Digital media provided both an awareness of shared grievances, and transportable strategies for action.

The prominent Bahraini human-rights blogger Mahmood al-Yousif tweeted during his arrest, instantly linking up the existing networks of local democratization activists such as @OnlineBahrain with international observers through @BahrainRights. In Libya, the first assertion of a competing political authority to that of Muammar Qadhafi came online, on a website declaring an alternative government in the form of an interim national council. One of 
Qadhafi's senior advisors defected by tweeting his resignation and urging Qadhafi to leave Libya.

Algerians, goaded by the same sense of economic despair and dissatisfaction that drove Tunisians and Egyptians, broke out in similar demonstrations. Salima Ghezali, a leading Algerian activist, told Al Jazeera that the protests were "both very local and very global.” Unionled strikes had been common in Algeria for decades, but nothing like the unrest of 2011 had been seen since 1991. Algerian protesters were not among the region's most tech-savvy, but before the country's state-run media reported on local protests or Mubarak's resignation, many residents of Algiers received the inspirational news via SMS.

\section{Digital Contexts, Political Consequences}

Ben Ali had ruled for almost twenty-five years, and Mubarak for nearly thirty. Each was tossed out of power by a network of activists whose core members were twenty-somethings with little experience in social-movement organizing or open political discourse. Seeing this, other governments scrambled to make concessions that they hoped would head off explosions. Algeria's rulers lifted an almost two-decade-old state of emergency. Oman's sultan gave its elected legislature the authority to pass laws. Sudan's war-criminal president promised not to seek reelection. All the oil-rich states committed to wealth redistribution or the extension of welfare services.

Real-world politics, of course, is about much more than what happens online. A classically trained social scientist trying to explain the Arab Spring would point to the youth bulge, declining economic productivity, rising wealth concentration, high unemployment, and low quality of life as common circumstances across the region. These explanatory factors are typically part of the story of social change, and it does not diminish digital media's causal contribution to note their presence. Such media were singularly powerful in spreading protest messages, driving coverage by mainstream broadcasters, connecting frustrated citizens with one another, and helping them to realize that they could take shared action regarding shared grievances. For years, discontent had been stirring, but somehow the drivers of protest never proved sufficient until mobile phones and the web began pervading the region. It never makes sense to look for simple, solitary causes of a revolution, to say nothing of a string of revolutions, and the precise grievances have varied significantly from country to country. Yet the use of digital media to rouse and organize opposition has furnished a common thread. ${ }^{2}$

It is true that journalists have focused on the visible technological tactics that seemed to bring so much success, rather than looking at the root causes of social discontent. Yet this does not mean that analysts should overcorrect and exclude information technologies from the list of causes altogether. Indeed, social discontent is not something ready-made, but must gestate as people come to agree on the exact nature and goals of their discontent. In the last few years, this gestation process has gone forward via new media, particularly in Tunisia, Egypt, and Bahrain. Social discontent can assume organizational form online, and can be translated into workable strategies and goals there as well. Over the last few months, this translation process has occurred via mobile phones and social-networking applications even in countries whose governments are very good at co-opting or brutally suppressing opposition, such as Syria, Yemen, and Saudi Arabia.

In the Middle East and North Africa, dissent existed long before the Internet. Yet digital media helped to turn individualized, localized, and community-specific dissent into a structured 
movement with a collective consciousness about both shared plights and opportunities for action. It may make more sense to think of conjoined causal combinations: the strength of existing opposition movements, the ability (or inability) of the regime to buy off opposition leaders, with the use of digital media to build opposition networks. The precise mixture of causes may have varied from country to country, but the one consistent component has been digital media.

\section{Understanding a (Possible) Wave}

It is premature to call these events a "wave" of democratization-their outcomes are still far too uncertain for that-yet we can say that opposition to authoritarian rule has been the consistent collective-action goal across the region. Arab social-movement leaders actively sought training and advice from the leaders of democratization movements in other countries, and rhetorical appeals for civil liberty appeared consistently from protest to protest.

As we look back over the first quarter of 2011, the story of digital media and the Arab Spring seems to have unfolded in five or perhaps six parts or phases. The first is a preparation phase that involves activists using digital media in creative ways to find each other, build solidarity around shared grievances, and identify collective political goals. The second is an ignition phase involving an incident that the state-run media ignore, but which comes to wide notice online and enrages the public. Then comes the third phase, a period of street protests made possible, in part, by online networking and coordination. As these are going on comes the international buy-in, during which digital-media coverage (much of it locally generated) draws in foreign governments, international organizations, global diasporas, and overseas news agencies. Matters then build toward a climax as the regime, maneuvering via some mixture of concession and repression, either gets the protesters off the street; fails to mollify or to intimidate them and begins to crumble before their demands; or ends up in a bloody stalemate as has happened in Bahrian, Syriaand Yemenor even degenerate into a full-blown civil war (as in Libya). In some cases, such as those of Tunisia and Egypt, we can see an additional phase of follow-on information warfare as the various players left standing compete to shape the future course of events by gaining control over the revolutionary narrative.

Across the region, the process of building up to political change involved "building down" the credibility of authoritarian regimes by investigating their corrupt practices. The best and perhaps the only place that critics could find for getting their message across was the Internet. Blogs, news websites, Twitter feeds, and political listservs offered spaces where women could debate on an equal footing with men, where policy alternatives could be discussed, and where regime secrets could be exposed. What set the scene for a dramatic event such as the occupation of a central square was the undramatic process of people buying cheap mobile phones or time online at cybercafés. The arrival of new digital technologies became an occasion for individuals to restructure the ways in which they produced and consumed content. When a political crisis flared, the new habits of technology use were already in place.

After 2000, new communications technologies spread rapidly across the Arab world. For many Arabs, especially in cities, reading foreign news online and communicating with friends and relatives abroad became habits. Digital media could become a near-term cause of political upheaval in 2011 precisely because they were already so popular. It may seem that digital-media use in times of political crisis is novel. But for residents of Tunis, Cairo, and other capitals, it was the sheer everydayness and familiarity of mobile phones that made them a proximate cause of political change. The revolution may be televised, and it is surely online. 
What ignites popular protest is not merely an act of regime violence such as the police beating Mohamed Bouazizi or Khaled Said, but the diffusion of news about the outrage by networks of family, friends, and then strangers who step in when the state-run media ignore the story. When Al Jazeera failed at first to cover digital activism in Syria, civic leaders there lobbied the influential network into producing a long documentary and featuring Syrian-activist content on its website. Consequently, interest in homegrown opposition to dictator Bashar alAsad grew rapidly both within the country and across the region.

Interestingly, the recent protest ignitions seem to have occurred without recognizable leaders. Charismatic ideologues, labor-union officials, and religious spokespeople have been noticeably absent (or at least they were at first). In Tunisia, the igniting event was Bouazizi's suicide. In Egypt, it was the Tunisian example. The rest of the region followed as scenes of demonstrators and fleeing dictators went out over Al Jazeera and social-media networks.

After ignition, the street battles of political upheaval began, albeit in a unique manner. Most of the protests in most of the countries were organized in unexpected ways that made it difficult for states to respond. The lack of individual leaders made it hard for authorities to know whom to arrest. Activists used Facebook, Twitter, and other sites to communicate plans for civic action, at times playing cat-and-mouse games with regime officials who were monitoring these very applications. In Libya, foes of the Qadhafi dictatorship took to Muslim online-dating sites in order to hide the arrangements for meetings and protest rallies. In Syria, the Asad regime had blocked Facebook and Twitter intermittently since 2007, but reopened access as protests mounted, possibly as a way of entrapping activists. When state officials began spreading misinformation over Twitter, activists used Google Maps to self-monitor and verify trusted sources. Then too, authorities often flubbed their information-control efforts. Mubarak disabled Egypt's broadband infrastructure yet left satellite and landline links alone. Qadhafi tried to shut down his country's mobile-phone networks, but they proved too decentralized.

News coverage of events in the region regularly revealed citizens using their mobile phone cameras to document events, and especially their own participation in them. In Tahrir Square, both the crowds and the crewmen of the tanks that were sent to watch them took pictures of one another for instant distribution to their various social networks. When army vehicles were abandoned, people clambered aboard and posed for their Facebook pages. Arrestees took pictures of themselves in custody. Some Egyptians speculated that the army did not act systematically against protesters because soldiers were made suddenly aware of their socially proximate connection to the square's occupants, and also because the troops knew that they were constantly on camera. In countries where the armed forces did act with aggression, including Bahrain and Syria, the resulting carnage was still documented. YouTube had to add a special waiver to its usual no-gore policy in order to allow shocking user content such as a mobile phone video of unarmed Syrian civilians_-including children-being shot by Asad’s troops.

Sooner or later, regime opponents must seek some form of international support, and this, too, has become a digitally mediated process. Domestic turmoil can eventually capture international attention. Of course, the degree to which a popular uprising finds an international audience depends on strategic relations with the West, but also on the proximity of social-media networks. Most technology users in most countries do not have the sophistication to work around state firewalls or keep up anonymous and confidential communications online. But in each country a handful of tech-savvy students and civil society leaders do have these skills, and they 
used them well during the first months of 2011. Learning from democracy activists in other countries, these information brokers used satellite phones, direct landline connections to ISPs in Israel and Europe, and software tools for protecting user anonymity in order to supply the international media with pictures of events on the ground-even when desperate dictators attempted to shut down national ISPs.

When conflicts between a regime and its domestic opposition come to a head, one or the other may give in, or else a stalemate (often punctuated by violent clashes) may ensue. Mounting tensions led several governments to make clumsy attempts at disconnecting citizens from the global digital "grid.” Banning access to social-media websites, powering down cell towers, or disconnecting Internet switching points in major cities were among the desperate tactics to which authoritarian regimes resorted as they strove to maintain control. Even short disruptions of connectivity were costly. Egypt lost at least US\$90 million to Mubarak’s only partly successful efforts to cut off digital communications. Perhaps even more damaging in the long run, this episode harmed the country's reputation among technology firms as a safe place to invest. In Tunisia, the situation was reversed: It was not the government but rather activist hackers—or "hacktivists," as many call themselves - who did the most economic damage by shutting down the national stock exchange.

When regimes struck back, their counterblows had digital components. Bahrain, Morocco, and Syria saw cyber-struggles to dominate Twitter traffic. Every country that experienced turmoil witnessed delays or disruptions in mobile phone and Internet service, but it is hard to say whether this was due to regime-driven shutdowns or overwhelming traffic volumes at moments of maximal uncertainty. Quite likely it was both. The zenith of crisis tended to mark the nadir of connectivity as regimes cracked down on large telecommunications providers while skyrocketing traffic was rerouted to a few small available digital switches.

The information wars that followed the protests of the Arab Spring began with the efforts of regimes to hide their tracks. In Egypt, the State Security Investigative Service-Mubarak's political police - did all it could to destroy its archives, though some records leaked online. The websites of activists, meanwhile, became portals for criticisms of the interim government and its leaders. The victors in a popular uprising generate ever more digital content, while deposed the supporters of failed dictators produce less and less. Deposed dictators find only a small audience online, while the entrepreneurial activists who served as important nodes in the social movement network find themselves with newfound leadership roles. By the time the protests are over, a few of the "digerati" such as Wael Ghonim find that they have become newly prominent public figures. And the public expectation for being able to use information technology to access political figures remains. When U.S. secretary of state Hillary Clinton was booked for a web chat with a popular Egyptian website, 6,500 questions were submitted in two days.

Traditional media sources also played an important role in the Arab Spring. Satellite television forged a strong sense of transnational identity across the region, and everyone recognized the importance of coverage in this medium: Both Mubarak and his information minister called television anchors personally to berate them for unflattering stories. Of the existing news organizations, Al Jazeera certainly enjoyed the highest profile and the most influence regionally. The network's Dima Khatib, a native of Syria, was the most prominent commentator on Tunisia when that country erupted, and she served as a key information broker for the revolution through her postings on Twitter. Al Jazeera had an exceptionally innovative new media team that converted its traditional news product for use on social-media sites and made good use of the existing social networks of its online users. But a key aspect of its success 
was its use of digital media to collect information and images from countries in which its journalists had been harassed or banned. These digital networks gave Al Jazeera's journalists access to more sources, and gave a second life to their news products. Indeed, the use of social media itself has become a news peg, with analysts eager to play with the meme of technologyinduced political change.

Regime responses varied in sophistication, but often seemed several technological paces behind the behavior of civil society. In February, during one of his televised speeches, Qadhafi interrupted his train of thought when an aide drew his attention to real-time coverage of his rant. Gaddafi had simply never encountered such instant feedback from a source that could not easily be silenced or punished. In Bahrain, the successful suppression of protest by the country's Sunnidominated monarchy gave it an opportunity to plug the security holes in its telecommunications network. Though never as severely challenged by demonstrators, Saudi Arabia's rulers have reorganized the server infrastructure of the Kingdom so that all Internet traffic there flows through exchange points that are physically located in Riyadh.

It is a mistake to build a theory of democratization around a particular kind of software, a single website, or a piece of hardware, or to label these social upheavals "Twitter Revolutions" or "WikiLeaks Revolutions." ${ }^{3}$ Nor does it make sense to argue that digital media can cause either dictators or their opponents to achieve or fall short of their goals. Technological tools and the people who use them must together make or break a political uprising.

\section{The Digital Scaffolding for Civil Society}

Digital media changed the tactics of democratization movements, and new information and communication technologies played a major role in the Arab Spring. We do not know, at the time of this writing in May 2011, where events in the various countries will lead, and whether or not change will come to the remaining, more recalcitrant authoritarian governments. But the consistent narrative arc of the uprisings in the Arab Spring involves digital media. The countries that experienced the most dramatic protests were among the region's most thoroughly wired, and their societies boasted large numbers of people with the technical knowledge to use these new media to strong effect.

In times of political crisis, technology firms may "lean forward" with new tools or applications introduced to serve an eager public (and in doing so, capture market share). In late January, for example, Google sped up its launch of Speak2Tweet, an application designed to translate phone calls into text messages as a means of bypassing Mubarak's Twitter blockade. Several tech firms built dedicated portals to allow in-country users to share content. But as Evgeny Morozov has pointed out, information technologies - and the businesses that design them-do not always end up supporting democratization movements. ${ }^{4}$ Opposition leaders in countries where political parties are illegal sometimes use pseudonyms to avoid government harassment. But doing so on Facebook is a violation of the company's user agreement, and so the company actually shut down one of the protest-group pages in December. Supporters eventually persuaded Facebook to reinstate the page, but the incident showed how businesses such as Facebook, YouTube, and Twitter may not fully appreciate the way in which their users treat these tools as public-information infrastructure, and not just as cool new applications in the service of personal amusement. Whereas Google has signed the Global Network Initiative-a compact for preventing web censorship by authoritarian governments-Facebook has refused to 
do so. It might be technically possible to require Facebook users in Western countries to use real identities while allowing people living under dictatorships to enjoy anonymity, but no such feature currently exists.

Absent digital media, would the Arab Spring still have occurred? It is hard to say. The Arab world has long had democratic activists, but never before had any toppled a dictator. Radio and television have long reached most Arabs, but only 10 to 20 percent of those living in a typical Middle Eastern or North African country can easily gain access to the Internet. Yet this minority is a strategic one, typically comprising an elite made up of educated professionals, young entrepreneurs, urban dwellers, and government workers. These are the people who formed the networks that initiated, coordinated, and sustained successful campaigns of civil disobedience against authoritarian rule. Looking at the other side of the coin, the countries with the lowest levels of technology proliferation have also tended to have the weakest democratization movements. As fascinating as it can be to think of counterfactual scenarios, it would be a mistake to see these as belonging on an equal footing with actual events in concrete cases concerning which we have ample empirical evidence. Counterfactuals and thought experiments can be fun, but in the search for patterns that is the social scientist's task, prominence should always be given to real cases and the real evidence they yield.

As we have noted, it is premature to assert that we are witnessing a wave of democratization. Several states are still in crisis. In countries where authoritarian governments have collapsed or made major concessions, it is hard to know whether stable democracies will emerge. Democratization waves are measured in years, not months. In 1998, Indonesia's Suharto fell when students using mobile phones successfully mobilized and caught his regime off guard, but it took a decade of difficult political conversations for democratic practices to become entrenched. The Arab Spring had a unique narrative arc, involved a particular community of nations, and caught most autocrats and analysts alike by surprise. Digital media are important precisely because they had a role in popular mobilizations against authoritarian rule that were unlike anything seen before in the region.

It is also noteworthy that a remarkable amount of political change has occurred in a surprisingly nonlethal manner. In Algeria, Egypt, Jordan, Morocco, and Tunisia, civil society leaders found that the security services showed a remarkable reluctance to move aggressively against protesters (and the Tunisian and Egyptian militaries did not want to move against them at all). Could this hesitancy have had anything to do with the large numbers of mobile phone cameras that demonstrators were carrying? Sadly, a distaste for the use of deadly violence by regime forces has not been evident in Bahrain, Libya, Saudi Arabia, Syria, and Yemen. Yet even in those cases it can at least be said that solid documentation of regime abuses or even atrocities has reached the international community, in no small part thanks to mobile phones.

Scholars of social movements, collective action, and revolution must admit that several aspects of the Arab Spring challenge our theories about how such protests work. These movements had an unusually distributed leadership. The first days of protest in each country were organized by a core group of literate, middle-class young people who had no particular affinities with any existing political parties or any ideologies stressing class struggle, religious fundamentalism, or pan-Arab nationalism. Broadcast and print media-long associated with the mobilization phase of democratization waves - took a decided back seat to communication via social networks. This communication, moreover, itself had a strongly "distributed" or lateral character, and did not consist of one or a few relatively simple ideological messages beamed by 
an elite at a less-educated mass public, but had more the character of a many-sided conversation among more or less equal individuals.

Seeing what has unfolded so far in the Middle East and North Africa, we can say more than simply that the Internet has changed the way in which political actors communicate with one another. Since the beginning of 2011, social protests in the Arab world have cascaded from country to country, largely because digital media have allowed communities to unite around shared grievances and nurture transportable strategies for mobilizing against dictators. In each country, people have used digital media to build a political response to a local experience of unjust rule. They were not inspired by Facebook; they were inspired by the real tragedies documented on Facebook. Social media have become the scaffolding upon which civil society can build, and new information technologies give activists things that they did not have before: information networks not easily controlled by the state and coordination tools that are already embedded in trusted networks of family and friends.

\section{NOTES}

${ }^{1}$ Doug McAdam, Political Process and the Development of Black Insurgency, 1930-1970 (Chicago: University of Chicago Press, 1982).

2 Philip N Howard, Digital Origins of Dictatorship and Democracy: The Internet and Political Islam (New York, NY: Oxford University Press, 2010).

${ }^{3}$ Elizabeth Dickinson, "The First WikiLeaks Revolution?" available at

http://wikileaks.foreignpolicy.com/posts/2011/01/13/wiki leaks_and_the_tunisia_protests. See also Andrew Sullivan, "Tunisia's Wikileaks Revolution," available at www.theatlantic.com/dailydish/archive/2011/01/tunisias-wikileaksrevolution/ 177242 .

${ }^{4}$ Evgeny Morozov, The Net Delusion: The Dark Side of Internet Freedom (New York: PublicAffairs, 2011). 